\title{
TV/Series
}

19 | 2021

Perfectionnisme et séries télévisées. Hommage à

Stanley Cavell (1926-2018)

\section{New Television in the University}

\section{Martin Shuster}

\section{(2) OpenEdition \\ Journals}

Electronic version

URL: https://journals.openedition.org/tvseries/5333

DOI: $10.4000 /$ tvseries.5333

ISSN: 2266-0909

Publisher

GRIC - Groupe de recherche Identités et Cultures

\section{Electronic reference}

Martin Shuster, "New Television in the University", TV/Series [Online], 19 | 2021, Online since 06 May 2021, connection on 14 May 2021. URL: http://journals.openedition.org/tvseries/5333 ; DOI: https:// doi.org/10.4000/tvseries.5333

This text was automatically generated on 14 May 2021.

\section{(c)}

$T V /$ Series est mis à disposition selon les termes de la licence Creative Commons Attribution - Pas d'Utilisation Commerciale - Pas de Modification 4.0 International. 


\title{
New Television in the University
}

\author{
Martin Shuster
}

\section{Introduction: Cavell and University, from cinema to new television}

1 The title of my essay is inspired by Stanley Cavell's essay, "Film in the University". In that essay, Cavell raises the question of what it might mean to conceive of film as part of a university curriculum. I want to pose the same question here about new television ${ }^{2}$. Cavell's discussion is particularly incisive because it is not afraid to ask a very simple question: "is film worth teaching badly3?" Or in his alternative formulation of the alleged same question, do we believe "that there are films the viewing of which is itself an education ${ }^{4}$ " It is this core question that can be taken to raise the question of whether film belongs to the curriculum of a university.

2 The current historical moment has moved far beyond Cavell's moment in the late 1970s -so much so that perhaps these types of questions no longer even make sense, or take on a tenor that makes them unwieldly or irrelevant. Cavell, for example, opens his essay by stressing that one aspect of the question of a curriculum is the question of "what one is willing to pay for its study". The present moment, with skyrocketing university debt (at least in the United States, but increasingly also globally), gives this question an odd tinge: we increasingly seem to be deciding that, apart from science, technology, engineering, and mathematics (STEM), no other fields are "worth" studying ${ }^{6}$. At the same time, the possibilities for a university curriculum are likely the most varied that they have ever been in the long history of the university, and the question of film appears largely settled, as does the question, of television. Both now have well-established histories of study within several disciplines within the university.

3 And yet, there is something at the core of Cavell's concerns that strikes me as incredibly pertinent to the question of new television in the contemporary university, albeit, perhaps in slightly modified form. If Cavell's core interest involves the necessity of (particular) film(s) towards an education, then I take it that, in Cavell's classic formulation, we are really concerned about the relationship between these films and 
philosophy, which Cavell cleverly terms "the education of grownups". If that's true, then the question of the relationship between new television and philosophy - i.e., whether it can be part of the education of grownups - cannot be settled simply by whether new television belongs to a current university or field of inquiry. Phrenology, after all, used to be a field.

\section{Two questions about new television and university}

There are two elements that I want to stress in asking about the place of new television in the contemporary university. First, inspired by Cavell, I want to ask whether there works of new television that the viewing of which is itself an education? Second, and most central for this essay, is the question of what the experience of new television presently amounts to and can amount to, both in the university and beyond. The first question, I take it, can only really be settled by proper criticism, and it seems to me, in large part, it has been settled affirmatively8: it just is the case that The Wire (David Simon, HBO, 2002-2008) reveals something important to us, about ourselves and our world, no less powerfully and ambitiously, than, say, Vasily Grossman's Life and Fate (1980); and the same is true, say, of The Sopranos (David Chase, HBO, 1999-2007) and Dostoevski's The Brothers Karamazov (1880), or Weeds (Jenji Kohan, Showtime, 2005-2012) or Veep (Armando Lannucci, HBO, 2012-2019); or Curb Your Enthusiasm (Larry David, HBO, 2000-2011 and 2017-) and works by Franz Kafka or Jorge Luis Borges or Flannery O'Connor (to be clear, my claim is not that these are alike in all of the relevant ways, that they are "doing the same thing" just in different media, but rather that there are family resemblances between them, even as that they all do what they do specific to their medium ... but I have chosen these works to make the case that new television now pursues a wide array of projects, fundamentally does an immense amount).

The second question, about the experience of new television, seems to me still to require more consideration. And here there are many threads to pull. On one hand, we might think about the experience to which new television responds. On the other hand, we might think about the experience of new television, what the experience of it produces and cultivates within and for us. With respect to the former, I have argued elsewhere that the mode of new television ought to be understood as exemplified by two features: the portrayal of a pervasive loss of normative authority across all institutions, with one notable exception, the family, which is marshaled and glorified as the last remaining site of normative authority 9 . With the increasing questioning of all of the institutions that make up late capitalism (brought to the fore most explicitly by climate change but also by the entire state political structure, which persistently produces genocide as an after effect ${ }^{10}$ ), we might say that with new television-like with film-we see the works of art that make up new television as "memorable public events, segments of the experiences, the memories, of a common life ${ }^{11}$ ". In such a case, "the difficulty of assessing them is the same as the difficulty of assessing everyday experience, the difficulty of expressing oneself satisfactorily, of making oneself find the words for what one is specifically interested to say ${ }^{12 "}$.

6 This immediately raises the second element of the question of experience posed above: how might we think about the experience of new television? What are we "interested to say" about it? A comprehensive answer to this question is not possible here, but not because there is no "we" here, i.e., because we cannot somehow agree or our answers 
are too varied (this would be to misunderstand the importance of ordinary language philosophy to the entire procedure: it just is the case that in such matters, I can rely only on my experience, and that is already a sort of political act, that speaks for other but not for some $\mathrm{e}^{13}$ ). A comprehensive answer is rather beyond the scope of this essay; instead, I want to focus on just one issue that strikes me as central to any assessment of the experience of new television: its temporality. To be clear, my interest in the temporality of new television is not to be taken as of a kind with the sort of interest that the field of television and media studies has shown to the term, where the temporality of the technology and delivery of television itself is the central focus ${ }^{14}$. Instead, my interest is in the temporality that a new television work of art requires or suggests through its consideration as a work of art that might be considered as whole. This might require some clarification. My sense is that, in large part, television studies has oriented itself around how television shows (and other moving images on television) come to be delivered, on what I might term the modality of television rather than the medium of television (of course, this is a rhetorical move on my part, since what counts as a medium is itself part of the topic of discussion). With the emergence of digital television, television studies has become open to the possibility of analyzing what appears on television-what is screened-as divorced from the modality of its delivery. To my mind, this suggests the possibility of analyzing them as works of art comparable to film, where now "the conditions are created of an elective encounter, potentially unique at the moment it happens, between a program 'taken out' of its proper context and a viewer who is 'isolated' in his or her own viewing ${ }^{15}$ ". No longer can the focus simply be on the "flow" of television or on its proclivity to "interruption" or any other facets of its technological apparatus or modes of viewing; instead, my sense is that new television series may be analyzed in the same way that say, film (or other traditional works of art-here chiefly painting or photography-are analyzed): through criticism that orients itself around the thought that what is under critical analysis is an organic whole (I realize that this claim will likely make most media studies scholars look at askance at me).

\section{Digital television and spiritual exercises}

7 With that said, I do think that there is a particular possibility of viewing that digital television opens up that is important; what digital technology has especially brought to the fore is the possibility of viewing an entire series in the confines of one's home (I say "brought to the fore" to highlight that this isn't entirely novel, as it was also available in earlier technologies like Video, DVD, Blu-ray, and so forth - my point is only that it is not ubiquitous, it really has "come of age"). This allows for a possibility that mimics the state of early cinema. In The World Viewed, Cavell writes about early cinema noting that, "when moviegoing was casual and we entered at no matter what point in the proceedings ${ }^{16 "}$. In such a case, "we took our fantasies ... and anonymity inside and left with them intact ${ }^{17 "}$ ". This no longer the case for cinema, where "now ... it feels as if the old casualness of moviegoing has been replaced by a casualness of movie viewing, in which I interpret as an inability to tolerate our own fantasies ${ }^{18}$. What Cavell is describing is a moment in cinema's history before the existence of proper genres or show times, and thereby before the existence of proper audiences, or audience reactions. As cinema evolved, however, and as show times became fixed and genres did also, the expectations for viewer reactions emerged (an audience laughs during 
romance comedies, cries during dramas, cringes during horror films, and so forth). What is interesting about the possibility of watching new television series in the confines of one's home is that this relationship to the early cinema screen is recreated there: one has capability to explore one's desires and fantasies, to ask oneself about one's relationship to what one is screening: do I laugh or cry? Why? Of course, genres exist within new television (perhaps even more so), but the potential lack of an audience and the existence of viewing within one's home opens up the possibility of such a relationship to what is on screen. When it comes to the viewer, anonymity and fantasy permeate the home ${ }^{19}$.

8 This facet of the experience of new television strikes me as important for proposing one way to place new television within the university (it is, of course, not the only one, one could equally well prioritize the process of watching as a fan-weekly, as episodes appear-and in the contexts of the temporality of the discussions that follow or even the fan fictions that arise-I simply do not here). Taking this aspect seriously, with its focus on self-experimentation, fantasy, anonymity, and so forth can allow one to situate the experience of new television within other experiments and pursuit within the process of human cultivation. The idea is that watching The Wire or Six Feet Under (Alan Ball, HBO, 2001-2005) in its entirety is a sort of spiritual exercise, no different in that regard, than reading Robert Musil's Man Without Qualities ( $1^{\text {st }}$ partial ed. from 1930) or Tolstoï's Anna Karenina (1877). Such works of art are transformative, they affect the way in which we see the world, they "each ground a way of taking ourselves and our worldly situation to be ${ }^{20}$ ". They have the potential to spark our cognitive capacities (in the sense of what we are able to see) as much as our imaginative capacities (in the sense of what we are able to see beyond). Needless to say, in the world of late capitalism, where such spiritual processes are largely absent, extinguished, or grossly on the wane, there is an urgency to the possibilities such spiritual exercises offer. Furthermore, unlike other arts, television has an extremely low bar for entry, requiring essentially no training or knowledge, making the process exceedingly available, we might even say democratic.

\section{Conclusion: The challenge of TV series for university}

9 To begin to conclude, the challenge in the university context becomes the temporality of these series. It is not easy to view, say, 50 hours of television, even over the course of a semester, especially with increasingly well-regulated class times and blocks by means of school registrars (we need to have time, of course, for sports, internships, clubs, and other "essential" university pursuits). Furthermore, even despite the possibilities offered by viewing in the domain of one's home, cultures of viewing are such that we and most especially students - oftentimes view in states of distraction, texting or talking or doing whatever other work is there to be completed.

10 To my mind, this suggests a question around the possibilities of re-watching that I can only raise here. One way to get at what I am suggesting is to note that one can re-watch a film in a state of distraction, but it is difficult, as a sort of intentional plan, to rewatch a series in distraction. The cognitive commitment is too great: one doesn't simply begin to re-watch a 50 hour series when faced with the possibility of distraction, it strikes me as an intention that an agent likely couldn't maintain (or could only for peculiar reasons). Such a commitment to re-watching requires something of the viewer 
(in a way that re-watching a film seems to me not to - one can re-watch a particular film dozens of times, in all sorts of states, but one would be hard pressed to re-watch, say, The Wire, a dozen times ${ }^{21}$ ). All of this requires more analysis, especially about the phenomenology of re-watching in these contexts (something beyond my scope here), but the important point for the present discussion is that if I am right about the intentionality of re-watching when it comes to new television series - that it requires a level of commitment, one that it would not be too much to call self-reflective or selfreflexive - then all of the interesting questions about whether there are television series that the watching of which is an education in itself ought in fact be understood as whether there are television series that are worth re-watching. And those questions then, it seems to me - again because of the temporality involved - pull us clearly out of the university context, highlighting the importance of discussions with friends, colleagues, and other fans, whether virtual or real. At the same time, though, we might say that the task of the university curriculum with respect to new television is the production of the possibility of re-watching, which includes then the exhibition of enough new television to lay the spark for re-watching, with the concomitant presentation of enough of a critical apparatus to make such re-watching worthwhile, truly spiritual. The objects of new television will take care of the rest.

\section{BIBLIOGRAPHY}

BuONANNo, Milly, The Age of Television: Experiences and Theories, trans. into English by Jennifer RADICE, Chicago, University of Chicago Press, 2008.

CAVELL, Stanley, "Leopards in Connecticut", The Georgia Review, vol. 30, n² 2, Summer 1976, p. 233-262; republished under the title "Film in the University", in Pursuits of Happiness: The Hollywood Comedy of Remarriage, Cambridge, Harvard University Press, 1981, p. 255-274.

CAVELL, Stanley, The World Viewed: Reflections on the Ontology of Film [1 $1^{\text {st }}$ ed.: 1971], enlarged edition, Cambridge, Harvard University Press, 1979.

CAVELL, Stanley, The Claim of Reason: Wittgenstein, Skepticism, Morality, and Tragedy, Oxford, Oxford University Press, 1979.

CAVELL, Stanley, Pursuits of Happiness: The Hollywood Comedy of Remarriage, Cambridge, Harvard University Press, 1981.

GIBSON, John, "Narrative and the Literary Imagination", in Narrative, Philosophy, and Life, ed. Allen SPEIGHT, New York, Springer, 2015, p. 135-150.

HARRIS, Malcolm, "What's Scarier Than Student Loans? Welcome to the World of Subprime Children", The New York Times, May 11, 2019, https://www.nytimes.com/2019/05/11/opinion/ sunday/student-loans.html.

JACOBS, Jason, “Television Interrupted: Pollution or Aesthetic”, in Television as Digital Media, eds. James BenNETT and Niki STRANGE, Durham, Duke University Press, 2011. 
JACOBSON, Kirsten, “A developed nature: A phenomenological account of the experience of home", Continental Philosophy Review, vol. 42, n 3, August 2009, p. 355-373, available on https:// www.researchgate.net/publication/

225741038_A_developed_nature_A_phenomenological_account_of_the_experience_of_home.

LEVENE, Mark, "Why Is the Twentieth Century the Century of Genocide?", Journal of World History, vol. $11, \mathrm{n}^{\circ}$ 2, 2000, p. 305-336.

LEVENE, Mark, Genocide in the Age of Nation State, 4 vols., London, I.B. Tauris, 2005.

LEVENE, Mark, CONVERSI, Daniele, "Subsistence Societies, Globalisation, Climate Change and Genocide: Discourses of Vulnerability and Resilience", The International Journal of Human Rights, vol. 18, n 3, 2014, p. 281-297.

NANNICELLI, Ted, Appreciating the Art of Television: A Philosophical Perspective, London, Routledge, 2016.

NOCHIMSON, Martha P., Television Rewired: The Rise of the Auteur Series, Austin, University of Texas Press, 2019.

NORRIS, Andrew, Becoming Who We Are: Politics and Practical Philosophy in the Work of Stanley Cavell, Oxford, Oxford University Press, 2017.

SHUSTER, Martin, New Television: The Aesthetics and Politics of a Genre, Chicago, University of Chicago Press, 2017.

\section{NOTES}

1. The essay "Film in the University" appears as the appendix to Stanley Cavell, Pursuits of Happiness: The Hollywood Comedy of Remarriage, Cambridge, Harvard University Press, 1981, p. 255-274. It was earlier published as Cavell, "Leopards in Connecticut", The Georgia Review, vol. 30, $n^{\circ} 2$, Summer 1976, p. 233-262.

2. I am using "new television" in the way in which I have glossed the term in Martin Shuster, New Television: The Aesthetics and Politics of a Genre, Chicago, University of Chicago Press, 2017.

3. Cavell, Pursuits of Happiness: The Hollywood Comedy of Remarriage, op. cit., p. 270.

4. Ibid.

5. Ibid., p. 266.

6. See for example the recent return of "income share agreements": Malcolm Harris, "What's Scarier Than Student Loans? Welcome to the World of Subprime Children", The New York Times, May 11, 2019, https://www.nytimes.com/2019/05/11/opinion/sunday/student-loans.html.

7. Stanley Cavell, The Claim of Reason: Wittgenstein, Skepticism, Morality, and Tragedy, Oxford, Oxford University Press, 1979, p. 125.

8. I would cite here also Ted Nannicelli, Appreciating the Art of Television: A Philosophical Perspective, London, Routledge, 2016, Shuster, New Television, op. cit., and Martha P. Nochimson, Television Rewired: The Rise of the Auteur Series, Austin, University of Texas Press, 2019.

9. See Shuster, New Television, op. cit., p. 122 and 173.

10. On both of these points, see Mark Levene, "Why Is the Twentieth Century the Century of Genocide?", Journal of World History, vol. 11, n², 2000, p. 305-336, Mark Levene, Genocide in the Age of Nation State, 4 vols., London, I.B. Tauris, 2005, and Mark Levene and Daniele Conversi, "Subsistence Societies, Globalisation, Climate Change and Genocide: Discourses of Vulnerability and Resilience", The International Journal of Human Rights, vol. 18, n 3, 2014, p. 281-297.

11. Cavell, Pursuits of Happiness: The Hollywood Comedy of Remarriage, op. cit., p. 41. 
12. Ibid.

13. This is a topic that Cavell has pursued throughout his work. It is given great summary in Andrew Norris, Becoming Who We Are: Politics and Practical Philosophy in the Work of Stanley Cavell, Oxford, Oxford University Press, 2017, p. 15-45 and 95-141.

14. The various issues around this discussion are summarized extremely well in Jason Jacobs, “Television Interrupted: Pollution or Aesthetic", in Television as Digital Media, ed. James Bennett and Niki Strange, Durham, Duke University Press, 2011.

15. Milly Buonanno, The Age of Television: Experiences and Theories, Chicago, University of Chicago Press, 2008, p. 69.

16. Stanley Cavell, The World Viewed: Reflections on the Ontology of Film [1 $1^{\text {st }}$ ed.: 1971], enlarged edition, Cambridge, Harvard University Press, 1979, p. 11. On this point, cf. Shuster, New Television, op. cit., p. 7.

17. Ibid.

18. Ibid.

19. See the phenomenological notion of "home," glossed in Kirsten Jacobson, "A developed nature: A phenomenological account of the experience of home", Continental Philosophy Review, vol. 42, n 3, August 2009, p. 355-373, available on https://www.researchgate.net/publication/ 225741038_A_developed_nature_A_phenomenological_account_of_the_experience_of_home.

20. John Gibson, "Narrative and the Literary Imagination", in Narrative, Philosophy, and Life, ed. Allen Speight, New York, Springer, 2015, p. 148.

21. This entire line of thinking about re-watching was suggested to me by Robert Pippin; I'm grateful to him for this question around re-watching with respect to new television.

\section{ABSTRACTS}

This paper is inspired by Stanley Cavell's paper, "Film in the University" (1976). It thinks about what role "new television" might play in the university curriculum. The analysis focuses on the temporality of new television, suggesting that because of its extended duration, new television can serve as a sort of spiritual exercise.

Cet article s'inspire de l'article de Stanley Cavell intitulé « Film in the University » (1976).

Il réfléchit au rôle que pourrait jouer la « nouvelle télévision » dans le curriculum universitaire.

L'analyse se concentre sur la temporalité de la nouvelle télévision, suggérant qu'en raison de sa durée prolongée, la nouvelle télévision peut servir à une sorte d'exercice spirituel.

\section{INDEX}

Keywords: aesthetics, Cavell Stanley, new television, spiritual exercises, university

Mots-clés: Cavell Stanley, esthétique, exercices spirituels, nouvelle télévision, université 


\section{AUTHOR}

\section{MARTIN SHUSTER}

Martin Shuster is assistant professor at Goucher College in Baltimore (MD), where he teaches in both the Center for the Geographies of Justice and the Center for Humanities. In addition to many articles and book chapters, he is the author of: Autonomy after Auschwitz: Adorno, German Idealism, and Modernity and New Television: The Aesthetics and Politics of a Genre, both published the University of Chicago Press, in 2014 and 2017 respectively.

Martin Shuster est assistant professor au Goucher College de Baltimore (Maryland), où il enseigne à la fois au Centre pour les géographies de la justice et au Centre pour les humanités. En plus de nombreux articles et chapitres de livres, il est l'auteur de : Autonomy after Auschwitz: Adorno, German Idealism, and Modernity and New Television: The Aesthetics and Politics of a Genre, tous deux publié aux University of Chicago Press, respectivement en 2014 et 2017. 